\title{
1 Evapotranspiration partitioning through in-situ oxygen isotope \\ 2 measurements in an oasis cropland
}

3

4 Xuefa Wen ${ }^{\text {a* }}$, Bin Yang ${ }^{\text {a,b }}$, Xiaomin Sun ${ }^{a}$, Xuhui Lee ${ }^{\text {c,d }}$

5

$6{ }^{a}$ Key Laboratory of Ecosystem Network Observation and Modeling, Institute of Geographic

$7 \quad$ Sciences and Natural Resources Research, Chinese Academy of Sciences, Beijing 100101, China

$8 \quad{ }^{b}$ University of Chinese Academy of Sciences, Beijing 100049, China

$9{ }^{c}$ Yale-NUIST Center on Atmospheric Environment, Nanjing University of Information Science \&

Technology, Nanjing 210044, China

$11{ }^{d}$ School of Forestry and Environmental Studies, Yale University, New Haven, Connecticut 06511,

12 USA

13

14

15

$16 *$ Corresponding author

17

Prof. Xuefa Wen, E-mail: wenxf@igsnrr.ac.cn; Tel: 86-10-64889272; Fax: 86-10-64858099

18

19

20 Submitted to Agricultural and Forest Meteorology (July 2015).

21

(C) 2015. This manuscript version is made available under the Elsevier user license http://www.elsevier.com/open-access/userlicense/1.0/ 
Abstract: The oxygen isotope compositions of ecosystem water pools and fluxes are useful tracers in the water cycle. As part of the Heihe Watershed Allied Telemetry Experimental Research (HiWATER) program, high-frequency and near-continuous in situ measurements of ${ }^{18} \mathrm{O}$ composition of atmospheric vapor $\left(\delta_{\mathrm{v}}\right)$ and of evapotranspiration $\left(\delta_{\mathrm{ET}}\right)$ were made with the flux-gradient method using a cavity ring-down spectroscopy water vapor isotope analyzer. At the sub-daily scale, we found, in conjunction with intensive isotopic measurements of other ecosystem water pools, that the differences between ${ }^{18} \mathrm{O}$ composition of transpiration $\left(\delta_{\mathrm{T}}\right)$ and of xylem water $\left(\delta_{\mathrm{x}}\right)$ were negligible in early afternoon (13:00-15:00 Beijing time) when ET approached the daytime maximum, indicating isotopic steady state. At the daily scale, for the purpose of flux partitioning, $\delta_{\mathrm{T}}$ was approximated by $\delta_{\mathrm{x}}$ at early afternoon hours, and the ${ }^{18} \mathrm{O}$ composition of soil evaporation $\left(\delta_{\mathrm{E}}\right)$ was obtained from the Craig-Gordon model with a moisture-dependent soil resistance. The relative contribution of transpiration to evapotranspiration ranged from 0.71 to 0.96 with a mean of $0.87 \pm 0.052$ for the growing season according to the isotopic labeling, which was good agreement with soil lysimeter measurements showing a mean transpiration fraction of $0.86 \pm 0.058$. At the growing season scale, the predicted ${ }^{18} \mathrm{O}$ composition of runoff water was within the range of precipitation and irrigation water according to the isotopic mass conservation. The ${ }^{18} \mathrm{O}$ mass conservation requires that the decreased $\delta^{18} \mathrm{O}$ of ET should be balanced by enhanced $\delta^{18} \mathrm{O}$ of runoff water.

Keywords: Evapotranspiration partitioning; HiWATER program; Isotope Ratio Infrared Spectroscopy (IRIS); Isotopic Steady State (ISS); Stable oxygen isotope 


\section{Introduction}

Heihe River, the second longest inland river of China, is located in the continental arid climate in the inland region of northwest China, in the transition zone between the westerlies and the southwest (summer) monsoon (Huang and Wen, 2014; Guo et al., 2015). The oasis agriculture in the middle and lower reaches of the Heihe River Basin is supported by the precipitation and snowmelt from the Qilian Mountains, where Heihe River originates (Yang et al., 2015). Water conservation is a top priority for scientific research. Vegetation transpiration $(\mathrm{T})$, through the stomata of plants and associated with plant productivity, and soil evaporation (E), not directly contributing to production, are the two components of evapotranspiration (ET). Research on the partitioning of ET in this region is of great interest to water resource managers. In addition, data on $\mathrm{E}$ and $\mathrm{T}$ are needed for validation of ecosystem models. Because $\mathrm{E}$ and $\mathrm{T}$ are controlled by different processes, the ability to separate ET into its components should improve the prediction of climatic responses of ecosystem functions and processes and our understanding of surface-atmosphere water and energy exchange (Li et al., 2013; Kool et al., 2014; Sutanto et al., 2014).

Although partitioning of ET has been performed for decades, using either isotopic or non-isotope approaches, the accuracy of the partitioned fluxes is still not satisfactory (Kool et al., 2014; Sutanto et al., 2014). The sources of errors mainly include assumption used in the analyses and instrument inaccuracy (Sutanto et al., 2014). In isotope-based approaches, water vapor fluxes produced by soil evaporation and plant 
transpiration have different oxygen and hydrogen isotope compositions because soil evaporation is much more fractionated than plant transpiration. The isotopic endmember difference provides the basis for ET partitioning (Yakir and Sternberg, 2000). Most partitioning studies focus on forest (Moreira et al., 1997; Wang and Yakir, 2000; Yepez et al., 2003, 2007; Williams et al., 2004; Lai et al., 2006; Robertson and Gazis, 2006; Xu et al., 2008; Dubbert et al., 2014b; Sun et al., 2014) and grassland ecosystems (Ferretti et al., 2003; Yepez et al., 2005; Wenninger et al., 2010; Sutanto et al., 2012; Dubbert et al., 2013; Hu et al., 2014), but few studies have been performed on cropland ecosystems (Wang and Yakir, 2000; Zhang et al., 2011). An advantage of cropland systems is that conventional non-isotope methods for the ET partitioning, such as the combination of micro-lysimeters to measure evaporation and eddy covariance to measure evapotranspiration (Kool et al., 2014; Sutanto et al., 2014), can be implemented to check the isotopic results. However, the micro-lysimeters have drawbacks of inability to measure during irrigation or rain, time consuming, and limited representation due to small sample size (Kool et al., 2014).

Combined with the eddy covariance technique, measurement of the oxygen isotope compositions of ecosystem water pools and fluxes can be used to partition the ET flux into its component fluxes. A key challenge is to precisely determine the ${ }^{18} \mathrm{O}$ composition of ET ( $\left.\delta_{\mathrm{ET}}\right)$ (Yakir and Sternberg, 2000; Sutanto et al., 2014). At the present time, most investigations have used the Keeling mixing model to infer $\delta_{\mathrm{ET}}$ 
indirectly (Wang et al., 2000;Williams et al., 2004). The Keeling method is unreliable for water vapor because of a large entrainment effect caused by strong gradients in the vapor isotope composition across the top of the atmospheric boundary layer (Lee et al., 2012). Other limitations of the Keeling method to water isotopes include the assumption that the isotopic composition of the evaporation and transpiration do not change during the measurement interval (typically 30-60 minutes), the loss of water vapor from the ecosystem only by turbulent mixing, and the varied concentration of atmospheric water vapor only resulting from background vapor and local evapotranspiration (Lee et al., 2007; Hu et al., 2014; Sutanto et al., 2014).

The second challenge is how to best capture dynamic variations of the ${ }^{18} \mathrm{O}$ composition of transpiration $\left(\delta_{\mathrm{T}}\right)$. To date, $\delta_{\mathrm{T}}$ can be determined with four approaches. In isotopic steady state (ISS), $\delta_{\mathrm{T}}$ is equal to the isotopic composition of plant source water and can be derived from direct measurements of xylem water $\left(\delta_{\mathrm{x}}\right)(\mathrm{e} . \mathrm{g}$. Moreira et al., 1997; Williams et al., 2004). In nonsteady state conditions, $\delta_{\mathrm{T}}$ can be estimated by models such as the Craig-Gordon (Craig and Gordon, 1965), the Dongman (Dongmann et al., 1974), and the Farquhar-Cernusak model (Farquhar and Cernusak, 2005). In addition, $\delta_{\mathrm{T}}$ can be also directly measured with leaf and branch chambers (Wang et al., 2010; Dubbert et al., 2014a). Finally, $\delta_{\mathrm{T}}$ can be calculated from the isotopic mass balance using measurement of the foliage water pool changes over time (Hu et al., 2014). The ISS assumption is frequently used in flux partitioning studies. However, model results demonstrate that ISS is only met for short (hourly) timescales 
at noon or in early afternoon (Welp et al., 2008). Few studies have evaluated the ISS assumption via water pool and flux measurements (Hu et al., 2014).

The third challenge is related to quantification of the ${ }^{18} \mathrm{O}$ composition of evaporation $\left(\delta_{\mathrm{E}}\right)$. Generally, $\delta_{\mathrm{E}}$ is calculated with the Craig-Gordon model (Craig and Gordon, 1965; Yepez et al., 2003; Williams et al., 2004; Hu et al., 2014), whose input variables include the isotopic composition of soil water at the evaporation front, isotopic composition of water vapor $\left(\delta_{\mathrm{v}}\right)$, relative humidity, and equilibrium and kinetic fractionation factors. The model calculation is most sensitive to $\delta_{\mathrm{v}}$ and the determination of soil evaporation front (Sutanto et al., 2014). The endmember $\delta_{\mathrm{E}}$ can be also measured directly with soil chambers (Dubbert et al., 2013; Dubbert et al., 2014b).

Over the last several years, isotope ratio infrared spectroscopy (IRIS) has permitted high-frequency and near-continuous in situ measurements of atmospheric $\delta_{\mathrm{v}}$ (Lee et al., 2005; Wen et al., 2008, 2012b; Griffis, 2013), providing an attractive alternative to the traditional method involving collection of samples with cold traps and subsequent measurement by isotope ratio mass spectrometry (IRMS) (Helliker et al., 2002). The $\delta_{\mathrm{v}}$ measurements of most previous studies (i.e., cold traps) are discrete and labor intensive (Moreira et al., 1997; Wang and Yakir, 2000; Yepez et al., 2003; Xu et al., 2008). Advances in measuring the atmospheric $\delta_{\mathrm{v}}$, together with the flux-gradient or eddy covariance technique, enables to quantification of $\delta_{\mathrm{ET}}$ (Wen et al., 2012a; Huang 
and Wen, 2014). To date, only a few studies have deployed $\delta_{\mathrm{ET}}$ measured with the micrometeorological methods for ET partitioning (Lee et al., 2007; Hu et al., 2014).

This study is concerned with the partitioning of ET into its components of $\mathrm{E}$ and $\mathrm{T}$ in an irrigated cropland. The experiment was conducted as part of the Heihe Watershed Allied Telemetry Experimental Research (HiWATER) program (Li et al., 2013). The ${ }^{18} \mathrm{O}$ signals of the three flux endmembers $\left(\delta_{\mathrm{ET}}, \delta_{\mathrm{E}}\right.$ and $\left.\delta_{\mathrm{T}}\right)$ were determined during the growing season of a maize crop, in the middle reaches of Heihe River Watershed in 2012 using the flux gradient approach. The specific objectives of this study are: (1) to characterize, in conjunction with intensive measurements of ${ }^{18} \mathrm{O}$ composition of the ecosystem water pools, isotopic steady state using isotopic mass balance at the sub-daily scale, (2) to characterize the temporal dynamics of the ${ }^{18} \mathrm{O}$ signals of ET, E and $\mathrm{T}$ at the daily to seasonal scale, and quantify the contribution of $\mathrm{T}$ to $\mathrm{ET}$ using isotopic labeling and lysimeter measurements.

\section{Materials and Methods}

\subsection{Site description}

The study site in Zhangye, Gansu Province was part of the Heihe Watershed Allied Telemetry Experimental Research (HiWATER) program (Li et al., 2013). This sites had good fetch $(>200 \mathrm{~m})$. The experiment was conducted in an arid artificial oasis spring maize in the middle reaches of the Heihe River Watershed $\left(38^{\circ} 51^{\prime} \mathrm{N}, 100^{\circ} 22^{\prime}\right.$ E, 1550m asl) in northwest China. Over the past five decades (1961 2010), the daily 
mean temperature was $7.4{ }^{\circ} \mathrm{C}$ and the mean annual precipitation was $128.7 \mathrm{~mm}$. The experiment was conducted from May 27 to September 22 (DOY 148-265) in 2012. Plastic films were used for water conservation, covering rate about $60 \%$ of the soil surface. Flood irrigation water was applied four times (DOY 158, 184, 210 and 238) during the growing season. Spring maize was planted on April 20 and harvested on September 22, 2012. The maximum LAI and maximum canopy height were $5.6 \mathrm{~m}^{2}$ $\mathrm{m}^{-2}$ and $2.1 \mathrm{~m}$, respectively. Additional details concerning site information and data acquisition are described by Huang and Wen (2014) and Yang et al. (2015).

\subsection{In-situ measurement of water vapor and evapotranspiration isotope ratios}

The isotopic composition of water vapor in surface air $\left(\delta_{\mathrm{v}}\right)$ was measured using a cavity ring-down spectroscopy (CRDS) water vapor isotope analyzer (Model L1102-i, Picarro Inc). The schematic diagram of the CRDS analyzer, its principle of operation, and its calibration procedure were described in Huang and Wen (Huang and Wen, 2014). Briefly, air was pumped from two heights above the crop through heated tubes to the analyzer for analysis. The heights of the two intakes were 0.5 and $1.5 \mathrm{~m}$ higher than the canopy and increased over the season from $0.6 \mathrm{~m}$ and $1.6 \mathrm{~m}$ above the ground at the beginning to $2.6 \mathrm{~m}$ and $3.6 \mathrm{~m}$ by the end of the maize season to adjust for canopy growth. The air samples were pumped through the analyzer sequentially with $120 \mathrm{sec}$ spent on each measurement. The step changes in the HDO, $\mathrm{H}_{2}{ }^{18} \mathrm{O}$ and $\mathrm{H}_{2}{ }^{16} \mathrm{O}$ mixing ratios in response to valve switching between two air sample intakes are given in Fig. 1, indicating that the measurement approached steady state in less than $30 \mathrm{~s}$ 
after each switching. For safety, 10 data points ( 50s) after switching was discarded in this study. The $\delta_{\mathrm{v}}$ was calibrated in every 3 h using three span gases (Wen et al. 2008, 2012a; Huang and Wen, 2014). Three span gases with same isotopic ratios were generated by the liquid vaporization module. Two of three were used to span the atmospheric concentration of water vapor for calibrating the measurements. The isotopic compositions of the calibration water were measured by a liquid water isotope analyzer (Model DLT-100, Los Gatos Research Inc.). The data reported were block-averaged to hourly intervals.

The molar flux isotope ratio $\left(R_{\mathrm{ET}}\right)$ of evapotranspiration $(\mathrm{ET})$ was determined by the flux-gradient technique using measurements at the two sampling heights above the canopy (Lee et al., 2007; Wen et al., 2012a; Hu et al., 2014; Huang and Wen, 2014). Here, $R_{\mathrm{ET}}$ was calculated hourly as

$$
R_{\mathrm{ET}}=R_{\mathrm{d}} \frac{x_{s, 2}^{16}-x_{s, 1}^{16}}{x_{s, 2}^{18}-x_{s, 1}^{18}} \frac{x_{a, 2}^{18}-x_{a, 1}^{18}}{x_{a, 2}^{16}-x_{a, 1}^{16}}
$$

where $R_{\mathrm{d}}$ is the molar ratio of the calibration water, $x$ is the hourly mean mixing ratio of water isotopologues, superscripts 16 and 18 denote the ${ }^{16} \mathrm{O}$ and ${ }^{18} \mathrm{O}$ molecules in water, subscripts $s, 1$ and $s, 2$ indicate span calibration vapor streams of 1 (lower) and 2 (higher), and subscripts $a, 1$ and $a, 2$ represent ambient air sampled at heights 1 (upper) and 2 (lower). The molar ratio $R_{\mathrm{ET}}$ was converted to the delta notation in reference to the VSMOW standard as

$$
\delta_{E T}=\left(R_{\mathrm{ET}} /_{R_{\mathrm{VSMOW}}}-1\right) \times 1000 \%
$$




\subsection{Measurement of isotopic compositions of ecosystem water pools}

Leaf, and stem, and soil samples were collected during 13:00 15:00 every 2-3 days

from one sampling plot except after irrigation events. Distances of sampling plot from the micrometeorological and isotopic towers were within the $30 \mathrm{~m}$. Previous studies had shown that the oxygen isotopic composition of leaf water could be pronounced enrichment along the leaf (e.g., Affek et al., 2006). Therefore, leaf samples from the upper and the lower canopy were archived separately, with main leaf vein removed, each sample being a mixture of small leaf sections cut from the upper, middle and bottom positions of the leaf. The root crown of one selected maize plant was sampled to represent the ${ }^{18} \mathrm{O}$ of the xylem water (Yang et al., 2015). Soil samples were collected from the depth of $0-5,5-10,10-20,20-30$ and $30-40 \mathrm{~cm}$, but also from the depth of 40-50, 50-60, 60-70, and 70-80 cm every 9 days. After each irrigation event, sampling of leaf, stem and soil was made during 13:00 15:00 for 7 consecutive days.

Four intensive campaigns were conducted during August 1-2, 17, 19-20, and 29-30 on sunny days. Collection of leaf, xylem and soil samples, and measurement of leaf water content were made every $3 \mathrm{~h}$ during the daytime (6:00 to 18:00) and $4 \mathrm{~h}$ during the nighttime (18:00 to 6:00). Leaf water content was determined with leaf samples from the upper and lower canopy.

A polyethylene bottle and a funnel were connected together to collect rain water. To prevent evaporation, a ping-pang ball was put into the funnel. We also collected dew 
water with a cotton swab before sunrise. After each irrigation event, irrigation water was collected from both sides of the field. All of these samples were placed in bottles, sealed with Parafilm and kept frozen in a refrigerator $(-15$ to $-20 \circ \mathrm{C})$ prior to water extraction.

Water in these solid samples was extracted cryogenically using a vacuum line. The liquid samples (soil, xylem, leaf, precipitation, dew and irrigation water) were analyzed for their isotope ratios on a liquid water isotope analyzer (Model DLT-100, Los Gatos Research). ${ }^{18} \mathrm{O}$ of xylem and leaf water were corrected for organic contaminant following the procedure following the procedure of Xiao et al. (2012), and cross-checked with the analysis by pyrolysis with a continuous flow method on a mass spectrometer (MAT 253, Finnigan Inc.). The bias error (IRIS minus IRMS) was $-0.11 \pm 0.12 \%$ after the correction. The precision of the liquid water isotope analyzer was typical better than $0.3 \%$ for $\mathrm{D}$ and $0.1 \%$ for ${ }^{18} \mathrm{O}$.

\subsection{Auxiliary measurement}

Supporting measurement consisted of an eddy covariance system (Model LI-7500,

Licor Inc., Lincoln, NB; Model CSAT-3, Campbell Scientific Inc., Logan, UT; Model CR3000, Campbell Scientific Inc., Logan, UT), which was installed at the $4.5 \mathrm{~m}$ height above the ground. All raw data were recorded at $10 \mathrm{~Hz}$, and the $30 \mathrm{~min}$ mean $\mathrm{CO}_{2} / \mathrm{H}_{2} \mathrm{O}$ fluxes were calculated and stored by the CR5000 data logger. In brief, double coordination rotation, and the Webb-Pearman-Leuning correction were 
performed, detail in Huang and Wen (2014). Micrometeorological variables (air temperature, relative humidity, wind speed, precipitation, soil temperature, and soil moisture) were recorded at $1 \mathrm{~Hz}$, with 30 min averages through a suite of micrometeorological sensors mounted above the canopy and in the soil. Additional details concerning data acquisition are further described in the literature (Xu et al., 2013; Liu et al., 2001, 2013). Nine homemade micro-lysimeters (10 cm in diameter, and $15 \mathrm{~cm}$ in depth) were pushed into the non-mulched soil to retrieve an undisturbed soil sample. Then, they were sealed at the bottoms, weighed manually and placed back into the soil. After a period of one day, they were re-weighed to provide daily measurement of soil evaporation.

\subsection{Theoretical considerations}

\subsubsection{Flux isotope endmembers}

The evapotranspiration flux (ET) consists of the plant transpiration (T) and the soil evaporation $(\mathrm{E})$. Their sign convention is such that a positive value indicates flux upward toward the atmosphere and a negative value indicates downward flux toward the ecosystem. Conservation principles require

$$
E T=E+T
$$

$$
\delta_{\mathrm{ET}} E T=\delta_{\mathrm{E}} E+\delta_{\mathrm{T}} T
$$

where $\delta_{\mathrm{ET}}, \delta_{\mathrm{E}}$ and $\delta_{\mathrm{T}}$ are the isotopic compositions of ET, E, and T, respectively. Here $\delta_{\mathrm{ET}}$ was measured with the gradient diffusion method, $\delta_{\mathrm{E}}$ was calculated according to the Craig-Gordon model, and $\delta_{\mathrm{T}}$ was determined according to the isotopic mass 
balance of the leaf water pool during the intensive campaigns or approximated by the

265 isotopic composition of the xylem water at midday under the ISS assumption.

Equations (3) and (4) form the basis for understanding the relationship of the soil

evaporation and plant transpiration to the evapotranspiration. If the isotopic

endmembers are known precisely, the fractional contributions of soil evaporation and plant transpiration to the evapotranspiration are given by

$$
\frac{\mathrm{E}}{\mathrm{ET}}=\frac{\delta_{\mathrm{T}}-\delta_{\mathrm{ET}}}{\delta_{\mathrm{T}}-\delta_{\mathrm{E}}}
$$

272 and

$$
\frac{\mathrm{T}}{\mathrm{ET}}=\frac{\delta_{\mathrm{ET}}-\delta_{\mathrm{E}}}{\delta_{\mathrm{T}}-\delta_{\mathrm{E}}}
$$

\subsubsection{Isotopic composition of plant transpiration}

276 Assuming the plant transpiration flux $\left(\mathrm{T}, \mathrm{g} \mathrm{H}_{2} \mathrm{O} \mathrm{m}^{-2} \mathrm{~s}^{-1}\right)$ equal to the difference between the water flux from xylem $\left(\mathrm{X}, \mathrm{g} \mathrm{H}_{2} \mathrm{O} \mathrm{m}^{-2} \mathrm{~s}^{-1}\right)$ and the time rate of change of canopy foliage water content $\left(\Delta L_{\mathrm{w}}, \mathrm{g} \mathrm{H}_{2} \mathrm{O} \mathrm{m}^{-2} \mathrm{~s}^{-1}\right)$, the mass fluxes and foliage pool of ${ }^{18} \mathrm{O}$ should be in balance. These conservation principles are given as where $\delta_{\mathrm{T}}, \delta_{\mathrm{X}}$ and $\delta_{\mathrm{L}}$ are the isotopic composition of plant transpiration, xylem water, and leaf water, respectively, and $L_{\mathrm{w}}$ is foliage water content $\left(\mathrm{g} \mathrm{H}_{2} \mathrm{O} \mathrm{m}{ }^{-2}\right)$, and were measured in the intensive campaigns. 
transpiration

$$
\delta_{\mathrm{T}}=\left[\delta_{\mathrm{X}}\left(T+\Delta L_{\mathrm{w}}\right)-\Delta\left(\delta_{\mathrm{L}} L_{\mathrm{w}}\right)\right] / T
$$

Because all the parameters in the right side of Equation (9) were known except for T, the solution for $\delta_{\mathrm{T}}$ can be achieved by incorporating Equation (6) into equation (9) (Hu et al., 2014).

\subsubsection{Isotopic composition of soil evaporation}

The isotopic composition of soil evaporation $\left(\delta_{\mathrm{E}}\right)$ was calculated using the

Craig-Gordon model (Craig and Gordon, 1965; Yakir and Sternberg, 2000)

$$
\delta_{\mathrm{E}}=\frac{\delta_{\mathrm{s}} / a_{\mathrm{e}}-h \delta_{\mathrm{v}}-\varepsilon_{\mathrm{eq}}-(1-h) \varepsilon_{\mathrm{k}}}{(1-h)+(1-h) \varepsilon_{\mathrm{k}} / 1000}
$$

where $\delta_{\mathrm{s}}$ represents the isotopic composition of liquid water at the evaporating front, approximated here by the isotopic composition of soil water at the $0-5 \mathrm{~cm}$ depth, $\alpha_{\mathrm{e}}$ is a temperature-dependent the equilibrium fractionation factor (Majoube, 1971), $\varepsilon_{\mathrm{eq}}=\left(1-1 / \alpha_{\mathrm{e}}\right) \times 1000$ is the equilibrium fractionation factor expressed in $\%$, $\varepsilon_{\mathrm{k}}$ is a kinetic factor, and $h$ is relative humidity normalized to the soil temperature at the $0-5 \mathrm{~cm}$ depth. In Equation (10), $h$ and $\delta_{\mathrm{v}}$ were measured at the upper intake of the CRDS analyzer. If diffusion is molecular, th $\varepsilon_{\mathrm{k}}$ is equal to $28 \%$ or $\mathrm{H}_{2}{ }^{18} \mathrm{O}$ (Merlivat, 1978). In canopy-scale studies, the variables in Equations (10) are measured above the canopy. According to Lee et al. (2009), $\varepsilon_{\mathrm{k}}$ should be calculated according to

$$
\varepsilon_{\mathrm{k}}=\left(28 r_{\mathrm{s}}+19 r_{\mathrm{b}}\right) /\left(r_{\mathrm{s}}+r_{\mathrm{b}}+r_{\mathrm{a}}\right)
$$

where the soil resistance $\left(r_{\mathrm{s}}\right)$, boundary-layer resistance $\left(r_{\mathrm{b}}\right)$, and aerodynamic resistance $\left(r_{\mathrm{a}}\right)$ and were calculated using data acquired by EC tower system 


\section{Results}

\subsection{Validation of the isotopic steady state assumption at early afternoon}

Fig. 2a illustrates the diurnal time series of $\delta_{\mathrm{T}}-\delta_{\mathrm{x}}$, ET flux during the intensive field

campaigns. The error bar represents one standard error of the observations made at the same time of the day. At sub-day time scales, the isotopic composition of T $\left(\delta_{\mathrm{T}}\right)$ was calculated during the intensive campaigns using isotopic mass balance (Equation 9). The flux (assumed equal to ET) weighted mean $\delta_{\mathrm{T}}$ and $\delta_{\mathrm{x}}$ were $-6.06 \%$ and $-5.93 \%$, respectively. The dependence of ensemble mean diurnal cycles of $\delta_{\mathrm{T}}-\delta_{\mathrm{x}}$ on the ET isotopic mass balance of the foliage water, $\delta_{\mathrm{T}}$ was lower than $\delta_{\mathrm{x}}$ in the morning as $\delta_{\mathrm{L}}$ increased with time, and greater than $\delta_{\mathrm{x}}$ in the evening as $\delta_{\mathrm{L}}$ decreased with time. In

Fig. 2, we relate $\delta_{\mathrm{T}}$ and $\delta_{\mathrm{x}}$ to ET by taking the difference between $\delta_{\mathrm{T}}$ and $\delta_{\mathrm{x}}$ to define afternoon hours (13:00-15:00).

\subsection{Seasonal variation of the three flux endmembers at early afternoon}

Fig. 3 illustrates seasonal variations in the ${ }^{18} \mathrm{O}$ composition of evapotranspiration $\left(\delta_{\mathrm{ET}}\right)$, evaporation $\left(\delta_{\mathrm{E}}\right)$, and transpiration $\left(\delta_{\mathrm{T}}\right)$ during early afternoon hours (13:00-15:00). 
Four irrigation events were indicated for reference. The $\delta_{\mathrm{ET}}$ value was averaged over the early afternoon hours (13:00-15:00). At this time of the day, $\delta_{\mathrm{T}}$ was approximated by the ${ }^{18} \mathrm{O}$ signal of xylem water $\left(\delta_{\mathrm{x}}\right)$ assuming ISS. Based on the isotopic and meteorological data acquired between 13:00-15:00, $\delta_{\mathrm{E}}$ was calculated from the

Craig-Gordon model. Because $T$ and $E$ are in same signs in Equation (4), mathematically $\delta_{\mathrm{ET}}$ must fall in the range bounded by $\delta_{\mathrm{T}}$ and $\delta_{\mathrm{E}}$, such that $\delta_{\mathrm{E}}<\delta_{\mathrm{ET}}<$ $\delta_{\mathrm{T}}$. Over the whole experimental period, the mean $\delta_{\mathrm{E}}$ and $\delta_{\mathrm{ET}}$ and $\delta_{\mathrm{T}}$ were (mean \pm one standard deviation) $-38.48 \pm 3.18 \%$, $-9.77 \pm 1.91 \%$ and $-5.74 \pm 0.92 \%$, respectively. The irrigation dates were 6 June (DOY 158, irrigation amount $111.6 \mathrm{~mm}$ ), 2 July (DOY 184, $141.9 \mathrm{~mm}$ ), 28 July (DOY 210, $149.7 \mathrm{~mm}$ ) and 25 August (DOY 238, $149.7 \mathrm{~mm}$ ) 2012. Because $80-90 \%$ of the Heihe River water originates from the upper mountainous area, the isotopic composition of the irrigation water $(-8.66 \pm 0.30 \%$ o $)$ was more depleted than the soil water (Yang et al., 2015). After each irrigation event, the three isotopic endmembers fluctuated obviously. Furthermore, $\delta_{\mathrm{E}}$ decreased more sharply than $\delta_{\mathrm{ET}}$ and $\delta_{\mathrm{T}}$.

\subsection{Isotopic partitioning at early afternoon}

The isotopic data were used to constrain the component fluxes (Fig. 3). Fig. 4 illustrates the relative contribution of transpiration (T) to evapotranspiration (ET) using isotopic labeling and the lysimeter/eddy covariance measurements. Also shown in Fig. 4 are leaf area index (LAI) and four irrigation events. In Fig. 4, the relative contribution of T to ET was evaluated in early afternoon (13:00-15:00) using isotopic 
labeling and at the whole day (0:00-24:00) using the lysimeter/eddy covariance measurement. Generally, the result of isotopic labeling was consistent with soil lysimeter measurements. During the growing season, the relative contribution of $\mathrm{T}$ to ET was $0.88 \pm 0.056$ and $0.85 \pm 0.088$ from isotopic labeling and from the lysimeter observation, respectively. However, a large discrepancy $(0.36 \pm 0.078)$ was observed right after the first irrigation event (DOY 158). The discrepancy for other irrigation events has a mean value of $0.04 \pm 0.012$. The lysimeter method could generally serve as a validation for other ET partition methods (Kool et al., 2014). The discrepancy after the first irrigation event was likely due to no canopy closure in the field. In this case, the isotopic composition of liquid water at the evaporating front was unreasonably approximated by the isotopic composition of soil water at the $0-5 \mathrm{~cm}$ depth. Excluding the result after the first irrigation event, the T/ET ratio varied from 0.71 to 0.96 , with the mean ( \pm one standard deviation) of $0.87( \pm 0.052)$ from isotopic labeling, and from 0.66 to 0.95 with the mean of $0.86( \pm 0.058)$ from the lysimeter observation, suggesting that our isotopic labeling approach was robust. The relative high contribution of soil evaporation was out of our expectation, because about $60 \%$ of the field was covered with plastic films. This might be due to the fact that the field was irrigated frequently during the growing season. Therefore, the available soil water for evaporation was always plentiful in the non-mulched soil. LAI decreased abruptly on DOY 218 due to removal of male maize plants. It also steeply dropped on DOY 257 because heavy frosts occurred in the late growing season. Wang et al. (2014) synthesized previous published papers and concluded that LAI has predominant 
impacts on T/ET. However, the percentage of T/ET declined slightly according to both the isotopic labeling and the lysimeter method (Fig. 4). This could be because of the high maize density of this field for seed production.

\subsection{Isotopic partitioning at the growing season scale}

Fig. 5 is a schematic representation of the average isotopic signals of various ecosystem water pools and fluxes during the growing season (DOY 148-265).

Numbers in parentheses indicate total fluxes in $\mathrm{mm}$. The analysis was restricted to seasonal time scale. The ${ }^{18} \mathrm{O}$ composition of ET, precipitation, dew and soil water were the mean values weighted by water vapor flux, precipitation amount, dew amount and soil water content, respectively. $\delta_{\mathrm{T}}$ was assumed to be the same as mean $\delta_{\mathrm{x}}$ weighted by water vapor flux in early afternoon (13:00-15:00). $\delta_{\mathrm{i}}$ was the algebraic mean of all the valid observations during the 4 irrigation events.

The seasonal total ET was $425.7 \mathrm{~mm}$ based on the eddy covariance. Giving the T/ET ratio of 0.87 for the growing season, this flux was partitioned as $56.0 \mathrm{~mm}$ for soil evaporation and $369.7 \mathrm{~mm}$ for plant transpiration. The mean $\delta_{\mathrm{ET}}$ and $\delta_{\mathrm{T}}$ were $-8.57 \%$ and $-5.83 \%$, respectively. According to the isotopic mass balance, $\delta_{\mathrm{E}}$ was $-26.93 \%$ during the growing season. As for the influxes during growing season, the total precipitation amount was $103.2 \mathrm{~mm}$ with the amount-weighted average isotopic composition of $-5.70 \%$. The total irrigation amount was $552.9 \mathrm{~mm}$, with an isotopic value of $-8.66 \%$. The amount of dewfall, calculated with the flux-profile method, was 
$9.9 \mathrm{~mm}$, equivalent to about $10 \%$ of the precipitation input. The frequency of dew formation was $59 \%$ in this site, and the amount-weighted average isotopic composition of dew water was $-4.05 \%$. The ${ }^{18} \mathrm{O}$ composition of the surface $(0-5 \mathrm{~cm})$, shallow $(5-40 \mathrm{~cm})$ and deep $(40-80 \mathrm{~cm})$ soil water were $-5.40 \%$, $-7.64 \%$, and $-7.81 \%$, respectively. The net change in soil water storage were $1.9 \mathrm{~mm},-4.7 \mathrm{~mm}$, and $7.4 \mathrm{~mm}$ between DOY 148 and DOY 265 in these soil layers. Over the growing season, the net change in soil water storage was negligible $(4.6 \mathrm{~mm})$ in comparison to the water fluxes.

According to isotopic mass conservation, ${ }^{18} \mathrm{O}$ composition of the deep percolation or runoff $(-7.37 \%$ ) was a little higher than deep soil water $(-7.81 \%)$, and within the range of precipitation and irrigation water. This is probably because it was calculated based on the ${ }^{18} \mathrm{O}$ mass conservation without considering the evaporation of dew water and intercepted rain. Overall, the ${ }^{18} \mathrm{O}$ mass conservation requires that the decreased ${ }^{18} \mathrm{O}$ composition of ET be balanced by enhanced ${ }^{18} \mathrm{O}$ composition of runoff water.

\section{Discussion}

In order to use the isotopic labeling approach to partition ET, we must first quantify the three end endmembers of $\delta_{\mathrm{T}}$ and $\delta_{\mathrm{E}}$ and $\delta_{\mathrm{ET}}$. Methods for determining these three end members have varying degrees of uncertainty (Kool et al., 2014; Sutanto et al., 2014). Several assumptions in the isotope mass balance model may contribute to uncertainty in the ET partitioning. 
Traditionally, $\delta_{\mathrm{ET}}$ is inferred by fitting the $\delta_{\mathrm{v}}$ to the inverse of water vapor mixing ratio with the Keeling plot approach (Yakir and Sternberg, 2000). The Keeling plot approach implicitly assumes that the observed temporal variations of $\delta_{\mathrm{v}}$ are attributable only to ET. In reality, $\delta_{\mathrm{v}}$ in the atmospheric surface layer are also influenced by processes unrelated to surface ET. For this reason, the intercept of

Keeling plot is an ambiguous quantity (Lee et al., 2006 , 2007 , 2012; Griffis et al., 2007). Measuring the atmospheric $\delta_{\mathrm{v}}$ with IRIS technique (Lee et al., 2005; Wen et al., $2008,2012 \mathrm{a})$, together with the flux-gradient technique, enabled us to quantify $\delta_{\mathrm{ET}}$ (Lee et al., 2007; Wang et al., 2010; Good et al., 2012; Wen et al., 2012b; Hu et al., 2014; Huang and Wen, 2014). However, the flux-gradient and Keeling plot methods were shown to have similar uncertainty of $5.83 \%$ and $5.89 \%$ for ${ }^{18} \mathrm{O}(\mathrm{Good}$ et al., 2012). Lee et al. (2007) reported an hourly precision of $1.4 \%$ or for $\delta_{\mathrm{ET}}$ with the flux-gradient approach through a series of laboratory tests. The uncertainty of $\delta_{\mathrm{ET}}$ could also be indicated by the standard error of $\delta_{\mathrm{ET}}$ within each hour in field implementation (Hu et al., 2014; Huang and Wen, 2014). For all the hourly data during the growing season, the average uncertainty of $\delta_{\mathrm{ET}}$ was $4.6 \%$ (ranging from $0.2 \%$ to $35.2 \%$ ) in our site (Huang et al., 2014). Over a temperate grassland, the $\delta_{\mathrm{ET}}$ uncertainty varies from $0.8 \%$ o to $53 \%$, with an average of $7.9 \%$ (Hu et al., 2014). Although the uncertainty of $\delta_{\mathrm{ET}}$ was huge for the entire day, it would approach to the minimum of uncertainty in early afternoon (13:00-15:00) when the water vapor gradient between the two sampling intakes reaches its maximum. Good et al. (2012) 
suggested that potential uncertainties of $\delta_{\mathrm{ET}}$ by the flux-gradient method mainly results from different footprints at the two intake heights, variability in atmospheric conditions, instrument precision, and the averaging method to calculate hourly $\delta_{\mathrm{ET}}$. At the sub-daily scale, the uncertainty is relatively small from $\delta_{\mathrm{T}}$ and $\delta_{\mathrm{E}}$ but quite large from $\delta_{\mathrm{ET}}$, so improving the precision of $\delta_{\mathrm{ET}}$ should be a priority (Hu et al., 2014). However, the uncertainty of $\delta_{\mathrm{ET}}$ (Fig. 3) was small in early afternoon (13:00-15:00) when the water vapor gradient between the two sampling intakes approached the maximum value of the diurnal cycle.

It is very challenging to capture the dynamic variations of $\delta_{\mathrm{T}}$, therefore, most of previous studies partitioning ET under steady state assumption (e.g. Moreira et al., 1997; Wang and Yakir, 2000; Ferretti et al., 2003; Williams et al., 2004). As an alternative to the ISS assumption, $\delta_{\mathrm{T}}$ can be estimated with the non-steady state leaf isotopic models (Dongmann et al., 1974; Farquhar and Cernusak, 2005). Estimating the water isotopic composition at the leaf evaporating front $\left(\delta_{\mathrm{L}, \mathrm{e}}\right)$ is critical to resolve $\delta_{\mathrm{T}}$ (Xiao et al., 2012). Many parameters are required for estimating $\delta_{\mathrm{L}, \mathrm{e}}$. One such parameter is the Péclet number, which is difficult to constrain at the canopy scale (Xiao et al., 2012; Hu et al., 2014). Because stomatal conductance is used for the leaf water balance calculation, meaningful results require that the conductance be measured hourly in the field or be computed with a robust photosynthesis model. In absence of data on these parameters, we were forced to adopt the ISS assumption, that $\delta_{\mathrm{T}}$ assume is the same as that of the xylem water $\left(\delta_{\mathrm{x}}\right)$. Our isotopic mass balance 
results illustrate that $\delta_{\mathrm{T}}$ at this site was not at ISS in the morning but rapidly approached and remained near ISS during the early afternoon (Fig. 2). Sutanto et al. (2014) reviewed that the ISS assumption is only valid at midday for short timescale (hourly) due to rapidly changing environmental conditions. Recent models studies show that the ISS assumption is satisfied during very limited midday hours (Farquhar and Cernusak, 2005; Yepez et al., 2005; Lai et al., 2006; Xiao et al., 2012). Our study is one of the few studies that evaluated ISS by measuring the foliage water pools and the flux in field conditions (Hu et al., 2014). The isotopic signal of plant transpiration $\left(\delta_{\mathrm{T}}\right)$ was so heavy and similar to surface soil water $(0-5 \mathrm{~cm})$ in this study. This was consistent with the results that more than $71 \%$ of the plant water was acquired from 0-5 cm soil layer in this plot (Yang et al., 2015). In addition, $\delta_{\mathrm{T}}$ can be also measured with chambers (Wang et al., 2010; Dubbert et al., 2014a).

The isotopic signal of soil evaporation $\left(\delta_{\mathrm{E}}\right)$ is generally estimated with the Craig-Gordon model. Key parameters in the model include $\delta_{\mathrm{v}}$, the isotopic composition of water at the soil evaporating front, and the kinetic fractionation factor appropriate for ambient conditions (Craig and Gordon, 1965; Yakir and Sternberg, 2000; Braud et al., 2009). In the present study, $\delta_{\mathrm{v}}$ was measured at fine (hourly) time scale resolutions. Recent studies have showed that $\delta_{\mathrm{v}}$ is variable at hourly, diurnal, and seasonal time scales due to influences by hydrological events such as precipitation, dew formation, and dew evaporation (Welp et al., 2008; Wen et al., 2012a). The determination of the evaporation front at the soil surface in case of 
saturation for determination of $\delta_{\mathrm{s}}$ should be considered carefully (Rothfuss et al., 2010). In this site, $\delta_{\mathrm{s}}$ was approximated here by the isotopic composition of soil water at the $0-5 \mathrm{~cm}$ depth. The kinetic fractionation factor associated with soil evaporation, $\varepsilon_{\mathrm{k}}$, was calculated as a weighted mean according to the soil resistance $\left(r_{\mathrm{s}}\right)$, the boundary-layer resistance $\left(r_{b}\right)$, and the aerodynamic resistance $\left(r_{a}\right)$ (Lee et al., 2009; Xiao et al., 2012). In this formulation, $\varepsilon_{\mathrm{k}}$ is a variable quantity, having lower values observed under moister soil conditions. For the data shown in Fig. 3, $\varepsilon_{\mathrm{k}}$ varied between $22.3 \%$ and $27.5 \%$. However, during the first flood irrigation event, $\delta_{\mathrm{s}}$ was unreasonably approximated by the isotopic composition of soil water at the $0-5 \mathrm{~cm}$ depth because of quickly change of the soil evaporation front in the exposed sunny conditions. In addition, the $\delta_{\mathrm{E}}$ can be also measured directly with soil chambers (Dubbert et al., 2013; Dubbert et al., 2014b). However, the chamber method would disturb the kinetics associated with evaporation.

To date, there is no consensus as to which ET partition method is most accurate, so an absolute validation of the isotopic method is not possible (Kool et al., 2014; Sutanto et al., 2014). In some partition methods, soil evaporation and plant transpiration are measured at different spatial scales. Micro-lysimeters are considered a reliable method to measure $\mathrm{E}$ and often serve, in conjunction of eddy covariance measurement, as validation for the isotopic labeling method (Kool et al., 2014). In a review of isotope-based studies, Sutanto et al. (2014) found that T contributes generally more than $70 \%$ to the ET, while other techniques lead to smaller T/ET. In this study, the 
result of isotopic labeling was in good agreement with soil lysimeter/eddy covariance measurements (Fig. 4). The E/ET ratio is expected to be greater when the atmospheric demand or water availability in the soil is higher. Kool et al. (2014) showed that E/ET seems to be particularly high (50-60\%) in flood irrigated systems. In their study, soil evaporation rates initially are high following the wetting event, but decline rapidly as the soil surface dries.

\section{Conclusions}

At the sub-daily scale, we relate $\delta_{\mathrm{T}}$ and $\delta_{\mathrm{x}}$ to ET by taking the difference between $\delta_{\mathrm{T}}$ and $\delta_{\mathrm{x}}$ to define the relationship between the non-steady state behaviors $\left(\delta_{\mathrm{T}}-\delta_{\mathrm{x}}\right)$ and ET. The differences between $\delta_{\mathrm{T}}$ and $\delta_{\mathrm{x}}$ were negligible when ET approached the daytime maximum, indicating that isotopic steady state (ISS) was reached during the early afternoon (13:00 - 15:00).

At the daily scale, excluding the result after the first irrigation event, the relative contribution of $\mathrm{T}$ to ET varied from 0.71 to 0.96 with the mean of $0.87 \pm 0.052$ for isotopic labeling, and from 0.66 to 0.95 with the mean of $0.86 \pm 0.058$ for lysimeter observations. The consistent results suggested that our isotopic labeling approach was robust $(p=0.446)$.

At the growing season scale (DOY 148-265), deep percolation (runoff water, $\delta_{\mathrm{R}}=$ $-7.37 \%$ ) has $\delta^{18} \mathrm{O}$ within the range of precipitation $\left(\delta_{\mathrm{p}}=-5.70 \%\right)$ and irrigation water 
$\left(\delta_{\mathrm{i}}=-8.66 \%\right)$ according to the prediction of isotopic mass conservation. Over the growing season, when net change in soil water storage become negligible $(4.6 \mathrm{~mm})$, the ${ }^{18} \mathrm{O}$ mass conservation requires that the decreased $\delta^{18} \mathrm{O}$ of ET $\left(\delta_{\mathrm{ET}}=-8.57 \%\right.$ ) be balanced by enhanced $\delta^{18} \mathrm{O}$ of runoff water.

\section{Acknowledgements}

This study was supported by the National Natural Science Foundation of China (Grant 91125002) and the Chinese Academy of Sciences Strategic Priority Research Program (Grant No. XDA05050601). XL also acknowledges support by the US National Science Foundation (Grant EAR-1520684). The data for this paper are available at the Data Center for Cold and Arid Region Sciences (http://westdc.westgis.ac.cn). Data set 1: Data set of stable isotopic observation (doi:10.3972/hiwater.108.2013.db). Data set 2: Data set of flux observation matrix (Daman Superstation, doi:10.3972/hiwater.073.2013.db). Data set 3: Data set of measurements of channel flow (doi: 10.3972/hiwater.123.2013.db).

\section{References}

Affek, H.P., Krisch, M.J., Yakir, D., 2006. Effects of intraleaf variations in carbonic anhydrase activity and gas exchange on leaf $\mathrm{C}^{18} \mathrm{OO}$ isoflux in Zea mays. New Phytol.169(2), 321-329.

Braud, I., Biron, P., Bariac, T., Richard, P., Canale, L., Gaudet, J.P.,Vauclin, M., 2009. Isotopic composition of bare soil evaporated water vapor. Part I: RUBIC IV experimental setup and results. J.Hydrol. 369 (1-2), 1-16. 
Craig, H.,Gordon, L., 1965. Deuterium and oxygen 18 variations in the ocean and the marine atmosphere. In: Tongiorgi E (ed). Stable Isotopes in Oceanographic Studies and Paleotemperatures. Laboratory of Geology and Nuclear Science, Pisa, Italy, 9-130.

Dongmann, G., Nürnberg, H., Förstel, H.,Wagener, K., 1974. On the enrichment of $\mathrm{H}_{2}{ }^{18} \mathrm{O}$ in the leaves of transpiring plants. Radiat. Environ. Bioph. 11 (1), 41-52.

Dubbert, M., Cuntz, M., Piayda, A., Maguas, C.,Werner, C., 2013. Partitioning evapotranspiration Testing the Craig and Gordon model with field measurements of oxygen isotope ratios of evaporative fluxes. J. Hydrol. 496, 142-153.

Dubbert, M., Cuntz, M., Piayda, A.,Werner, C., 2014a. Oxygen isotope signatures of transpired water vapor: the role of isotopic non-steady-state transpiration under natural conditions. New Phytol. 203 (4), $1242-1252$.

Dubbert, M., Piayda, A., Cuntz, M., Correia, A.C., Silva, F.C.E., Pereira, J.S.,Werner, C., 2014b. Stable oxygen isotope and flux partitioning demonstrates understory of an oak savanna contributes up to half of ecosystem carbon and water exchange. Front. Plant Sci. 5: 530. doi: 10.3389/fpls.2014.00530.

Farquhar, G.,Cernusak, L., 2005. On the isotopic composition of leaf water in the non-steady state. Funct. Plant Biol. 32 (4), 293-303.

Ferretti, D.F., Pendall, E., Morgan, J.A., Nelson, J.A., LeCain, D.,Mosier, A.R., 2003. Partitioning evapotranspiration fluxes from a Colorado grassland using stable isotopes: Seasonal variations and ecosystem implications of elevated atmospheric $\mathrm{CO}_{2}$. Plant Soil 254 (2), 291-303.

Good, S.P., Soderberg, K., Wang, L.X.,Caylor, K.K., 2012. Uncertainties in the assessment of the isotopic composition of surface fluxes: A direct comparison of techniques using laser-based water 
Griffis, T.J., Zhang, J., Baker, J.M., Kljun, N.,Billmark, K., 2007. Determining carbon isotope signatures from micrometeorological measurements: Implications for studying biosphere-atmosphere exchange processes. Bound. Lay. Meteorol. 123 (2), 295-316.

Griffis, T.J., 2013. Tracing the flow of carbon dioxide and water vapor between the biosphere and atmosphere: A review of optical isotope techniques and their application. Agric. For. Meteorol. 174, 85-109.

Guo, X.Y., Feng, Q., Wei, Y.P., Li, Z.X.,Liu, W., 2015. An overview of precipitation isotopes over the Extensive Hexi Region in NW China. Arab. J. Geosci. 8 (7), 4365-4378.

Helliker, B., Roden, J., Cook, C.,Ehleringer, J., 2002. A rapid and precise method for sampling and determining the oxygen isotope ratio of atmospheric water vapor. Rapid Commun. Mass Spectrom. $16(10), 929-932$.

Hu, Z.M., Wen, X.F., Sun, X.M., Li, L.H., Yu, G.R., Lee, X.H.,Li, S.G., 2014. Partitioning of evapotranspiration through oxygen isotopic measurements of water pools and fluxes in a temperate grassland. J. Geophys. Res. 119 (3), 358-371.

Huang, L.J.,Wen, X.F., 2014. Temporal variations of atmospheric water vapor $\delta \mathrm{D}$ and $\delta^{18} \mathrm{O}$ above an arid artificial oasis cropland in the Heihe River Basin. J. Geophys. Res. 119 (19), 11456-11476.

Keeling, C.D., 1958. The concentration and isotopic abundances of atmospheric carbon dioxide in rural areas. Geochim. Cosmochim. Ac. 13 (4), 322-334.

Kool, D., Agam, N., Lazarovitch, N., Heitman, J.L., Sauer, T.J.,Ben-Gal, A., 2014. A review of approaches for evapotranspiration partitioning. Agric. For. Meteorol. 184, 56-70.

Lai, C.T., Ehleringer, J.R., Bond, B.J.,U, K.T.P., 2006. Contributions of evaporation, isotopic 
non-steady state transpiration and atmospheric mixing on the $\delta^{18} \mathrm{O}$ of water vapour in Pacific Northwest coniferous forests. Plant Cell Environ. 29 (1), 77-94.

Lee, X., Sargent, S., Smith, R.,Tanner, B., 2005. In situ measurement of the water vapor ${ }^{18} \mathrm{O} /{ }^{16} \mathrm{O}$ isotope ratio for atmospheric and ecological applications. J. Atmos. Ocean. Tech. 22 (5), 555-565.

Lee, X., Smith, R.,Williams, J., 2006. Water vapour ${ }^{18} \mathrm{O} /{ }^{16} \mathrm{O}$ isotope ratio in surface air in New England, USA. Tellus B 58 (4), 293-304.

600

601

602

Lee, X., Kim, K.,Smith, R., 2007. Temporal variations of the ${ }^{18} \mathrm{O} /{ }^{16} \mathrm{O}$ signal of the whole-canopy transpiration in a temperate forest. Global Biogeochem. Cycles, 21 (3), GB3013,

Lee, X., Griffis, T., Baker, J., Billmark, K., Kim, K.,Welp, L., 2009. Canopy-scale kinetic fractionation of atmospheric carbon dioxide and water vapor isotopes. Global Biogeochem. Cycles, 23 (1),

Lee, X., Huang, J.P.,Patton, E.G., 2012. A large-eddy simulation study of water vapour and carbon dioxide isotopes in the atmospheric boundary layer. Bound. Lay. Meteorol. 145 (1), 229-248. Wen, J.G., Li, H.Y., Zhu, G.F., Guo, J.W., Ran, Y.H., Wang, S.G., Zhu, Z.L., Zhou, J., Hu, X.L.,Xu, Z.W., 2013. Heihe watershed allied telemetry experimental research (HiWATER): eddy-covariance systems and large aperture scintillometers in the Hai River Basin, China. Journal of Hydrology. 487, 24-38. 

eddy-covariance and large aperture scintillometer measurements with respect to the energy balance closure problem. Hydrol. Earth Syst. Sci. 15, 1291-1306.

Majoube, M., 1971. Oxygen-18 and deuterium fractionation between water and steam. J. Chim.Phys. Chim. Biolo. 68 (10), 1423-1436.

Merlivat, L., 1978. Molecular diffusivities of $\mathrm{H}_{2}{ }^{16} \mathrm{O}, \mathrm{HD}^{16} \mathrm{O}$ and $\mathrm{H}_{2}{ }^{18} \mathrm{O}$ in gases. J. Chem. Phys. 69(6), 2864-2871.

Moreira, M.Z., Sternberg, L.D.L., Martinelli, L.A., Victoria, R.L., Barbosa, E.M., Bonates, L.C.M.,Nepstad, D.C., 1997. Contribution of transpiration to forest ambient vapour based on isotopic measurements. Global Change Biol. 3 (5), 439-450.

Robertson, J.A.,Gazis, C.A., 2006. An oxygen isotope study of seasonal trends in soil water fluxes at two sites along a climate gradient in Washington state (USA). J. Hydrol. 328 (1-2), 375-387.

Rothfuss, Y., Biron, P., Braud, I., Canale, L., Durand, J.L., Gaudet, J.P., Richard, P., Vauclin, M.,Bariac, T., 2010. Partitioning evapotranspiration fluxes into soil evaporation and plant transpiration using water stable isotopes under controlled conditions. Hydrol. Process. 24 (22), 3177-3194.

Sun, S.J., Meng, P., Zhang, J.S., Wan, X.C., Zheng, N.,He, C.X., 2014. Partitioning oak woodland evapotranspiration in the rocky mountainous area of North China was disturbed by foreign vapor, as estimated based on non-steady-state O-18 isotopic composition. Agric. For. Meteorol. 184, $36-47$

Sutanto, S.J., Wenninger, J., Coenders-Gerrits, A.M.J.,Uhlenbrook, S., 2012. Partitioning of evaporation into transpiration, soil evaporation and interception: A comparison between isotope measurements and a HYDRUS-1D model (vol 16, pg 2605, 2012). Hydrol. Earth Syst. Sci. 16 (9), 
Sutanto, S.J., van den Hurk, B., Dirmeyer, P.A., Seneviratne, S.I., Rockmann, T., Trenberth, K.E., Blyth, E.M., Wenninger, J.,Hoffmann, G., 2014. HESS Opinions "A perspective on isotope versus non-isotope approaches to determine the contribution of transpiration to total evaporation". Hydrol. Earth Syst. Sci. 18 (8), 2815-2827.

Wang, L.X., Caylor, K.K., Villegas, J.C., Barron-Gafford, G.A., Breshears, D.D.,Huxman, T.E., 2010. Partitioning evapotranspiration across gradients of woody plant cover: Assessment of a stable isotope technique. Geophys. Res. Lett. 37, L09401, doi: 10.1029/2010GL043228.

Wang, L.X., Good, S.P., Caylor, K.K., 2014. Global synthesis of vegetation control on 549-561.

Welp, L., Lee, X., Kim, K., Griffis, T., Billmark, K.,Baker, J., 2008. $\delta^{18} \mathrm{O}$ of water vapour, evapotranspiration and the sites of leaf water evaporation in a soybean canopy. Plant cell environ.

$$
31(9), 1214-1228 .
$$

Wen, X., Sun, X., Zhang, S., Yu, G., Sargent, S.,Lee, X., 2008. Continuous measurement of water vapor $\mathrm{D} / \mathrm{H}$ and ${ }^{18} \mathrm{O} /{ }^{16} \mathrm{O}$ isotope ratios in the atmosphere. J. Hydrol. 349 (3-4), 489-500.

Wen, X., Lee, X., Sun, X., Wang, J., Hu, Z., Li, S.,Yu, G., 2012a. Dew water isotopic ratios and their relationships to ecosystem water pools and fluxes in a cropland and a grassland in China. Oecologia, commercial analyzers for water vapor isotope measurement. J. Atmos. Ocean. Tech. 29 (2), 
661

662

663

664

665

666

667

668

669

670

671

672

673

674

675

676

677

678

679

680

Wenninger, J., Beza, D.T.,Uhlenbrook, S., 2010. Experimental investigations of water fluxes within the soil-vegetation-atmosphere system: Stable isotope mass-balance approach to partition evaporation and transpiration. Phys. Chem. Earth 35 (13-14), 565-570.

Williams, D.G., Cable, W., Hultine, K., Hoedjes, J.C.B., Yepez, E.A., Simonneaux, V., Er-Raki, S., Boulet, G., de Bruin, H.A.R., Chehbouni, A., Hartogensis, O.K.,Timouk, F., 2004. Evapotranspiration components determined by stable isotope, sap flow and eddy covariance techniques. Agric. For. Meteorol. 125 (3-4), 241-258.

Xiao, W., Lee, X., Griffis, T.J., Kim, K., Welp, L.R.,Yu, Q., 2010. A modeling investigation of canopy-air oxygen isotopic exchange of water vapor and carbon dioxide in a soybean field. J. Geophys. Res. 115, G01004, doi: 10.1029/2009JG001163.

Xiao, W., Lee, X., Wen, X., Sun, X.,Zhang, S., 2012. Modeling biophysical controls on canopy foliage water ${ }^{18} \mathrm{O}$ enrichment in wheat and corn. Global Change Biol. 18 (5), 1769-1780.

Xu, Z., Yang, H.B., Liu, F.D., An, S.Q., Cui, J., Wang, Z.S.,Liu, S.R., 2008. Partitioning evapotranspiration flux components in a subalpine shrubland based on stable isotopic measurements. Bot. Stud. 49 (4), 351-361.

Xu, Z.W., Liu, S.M., Li, X., Shi, S.J., Wang, J.M., Zhu, Z.L., Xu, T.R., Wang, W.Z., and Ma, M.G. 2013. Intercomparison of surface energy flux measurement systems used during the HiWATER-MUSOEXE, J. Geophys. Res. Atmos. 118, 13140-13157.

Yakir, D.,Sternberg, L.S.L., 2000. The use of stable isotopes to study ecosystem gas exchange. Oecologia, 123 (3), 297-311.

681 Yang, B., Wen, X.F.,Sun, X.M., 2015. Irrigation depth far exceeds water uptake depth in an oasis 
683 Yepez, E.A., Williams, D.G., Scott, R.L.,Lin, G.H., 2003. Partitioning overstory and understory 684 evapotranspiration in a semiarid savanna woodland from the isotopic composition of water vapor. 685 Agric. For. Meteorol. 119 (1-2), 53-68.

686 Yepez, E.A., Huxman, T.E., Ignace, D.D., English, N.B., Weltzin, J.F., Castellanos, A.E.,Williams, D.G., 2005. Dynamics of transpiration and evaporation following a moisture pulse in semiarid grassland: A chamber-based isotope method for partitioning flux components. Agric. For. Meteorol. $132(3-4), 359-376$.

Yepez, E.A., Scott, R.L., Cable, W.L.,Williams, D.G., 2007. Intraseasonal variation in water and carbon dioxide flux components in a semiarid riparian woodland. Ecosystems, 10 (7), 1100-1115. 
698 Fig. 1. Step changes in the $\mathrm{H}_{2}{ }^{18} \mathrm{O}$ (a) and $\mathrm{H}_{2}{ }^{16} \mathrm{O}$ (b) mixing ratios in response to valve switching between two air sample intakes.

Fig. 2. Mean diurnal time series of the difference between the $\delta^{18} \mathrm{O}$ of transpiration $\left(\delta_{\mathrm{T}}\right)$ and xylem $\left(\delta_{\mathrm{x}}\right)$, evapotranspiration (ET) during the intensive field campaigns (a). Dependence of $\delta_{\mathrm{T}}-\delta_{\mathrm{x}}$ on ET is also shown (b).

Fig. 3. Seasonal variation of the $\delta^{18} \mathrm{O}$ of evapotranspiration $\left(\delta_{\mathrm{ET}}\right)$, evaporation $\left(\delta_{\mathrm{E}}\right)$, and transpiration $\left(\delta_{\mathrm{T}}\right.$, equal to

Fig. 4. Relative contribution of transpiration (T) to evapotranspiration (ET) using isotopic labeling and lysimeter/eddy covariance measurement. Leaf area index (LAI) and four irrigation events are also shown for reference. The error bar (one standard error) is also shown.

Fig. 5. A schematic representation of average isotopic signals $\left(\delta^{18} \mathrm{O}\right)$ of various ecosystem water pools and fluxes during the growing season. Numbers in parentheses indicate total fluxes in mm. 
Figure 1
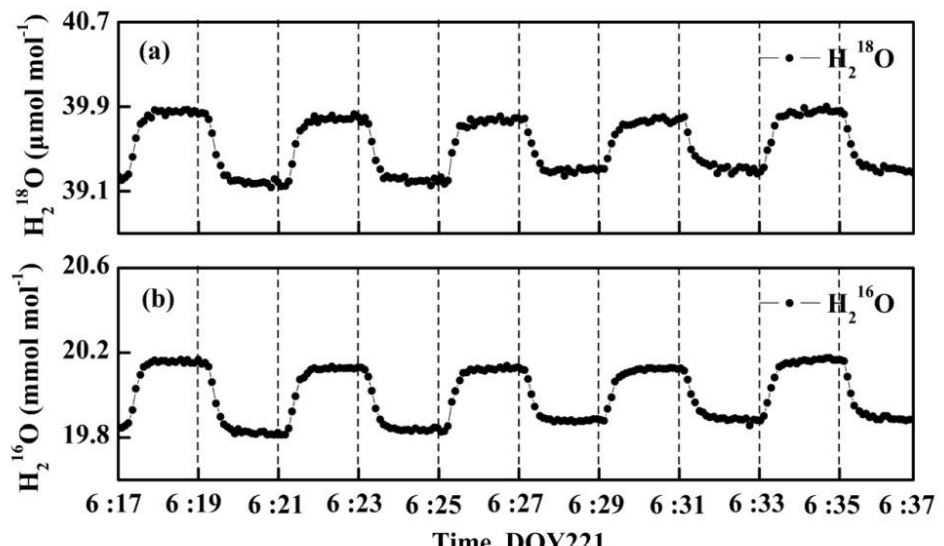

716

717 
Figure 2
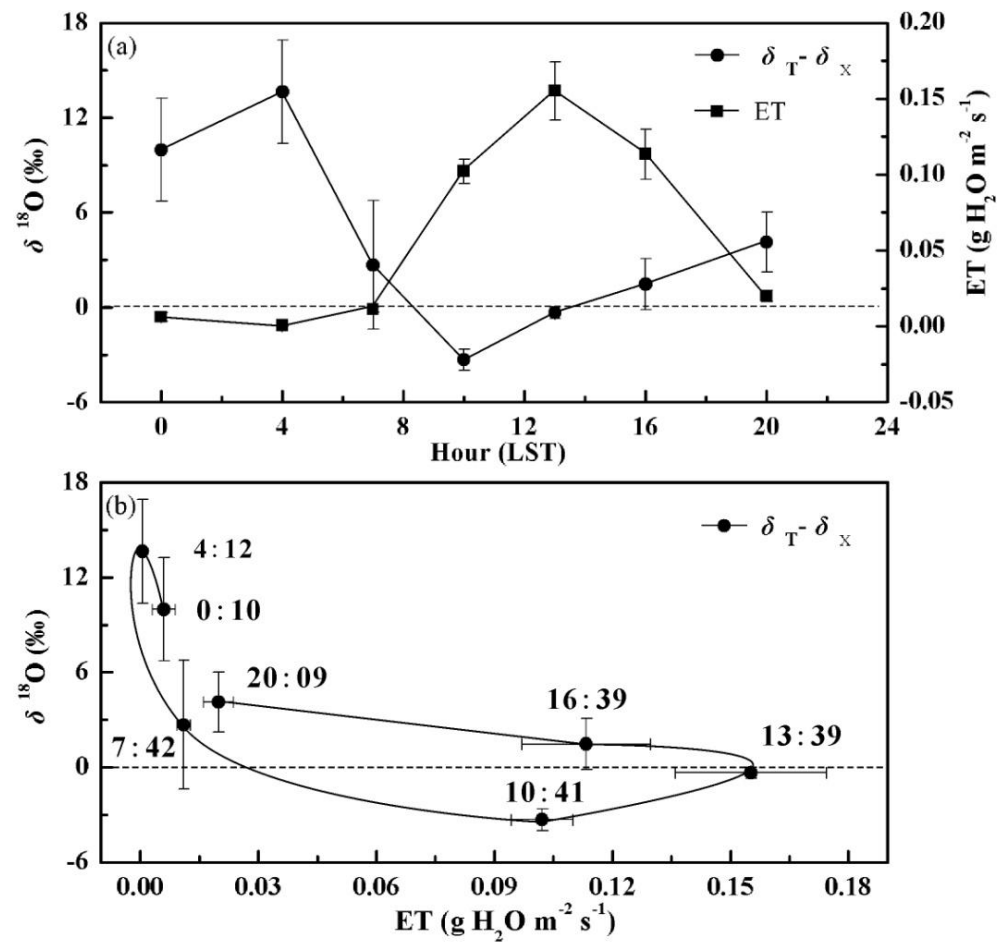

719 
Figure 3

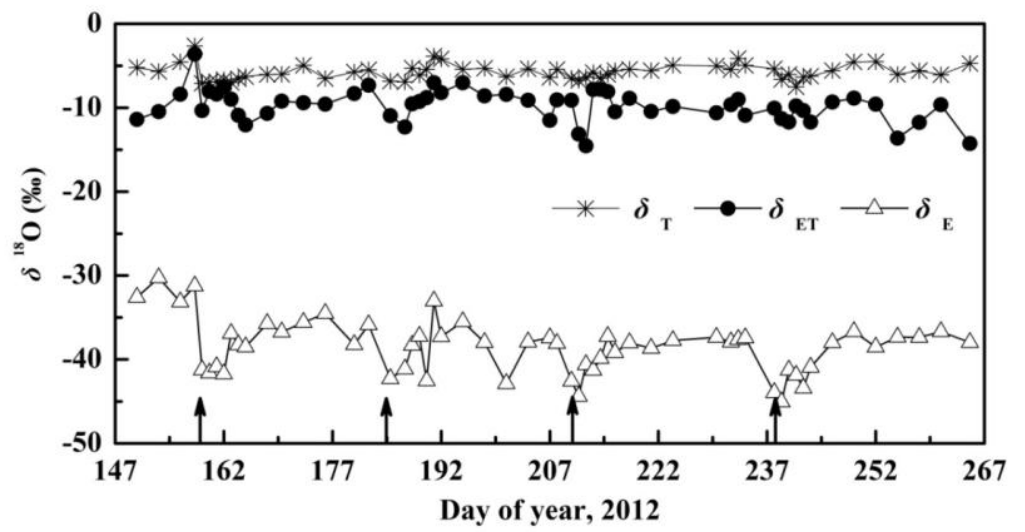

723

724 
$726 \quad$ Figure 4

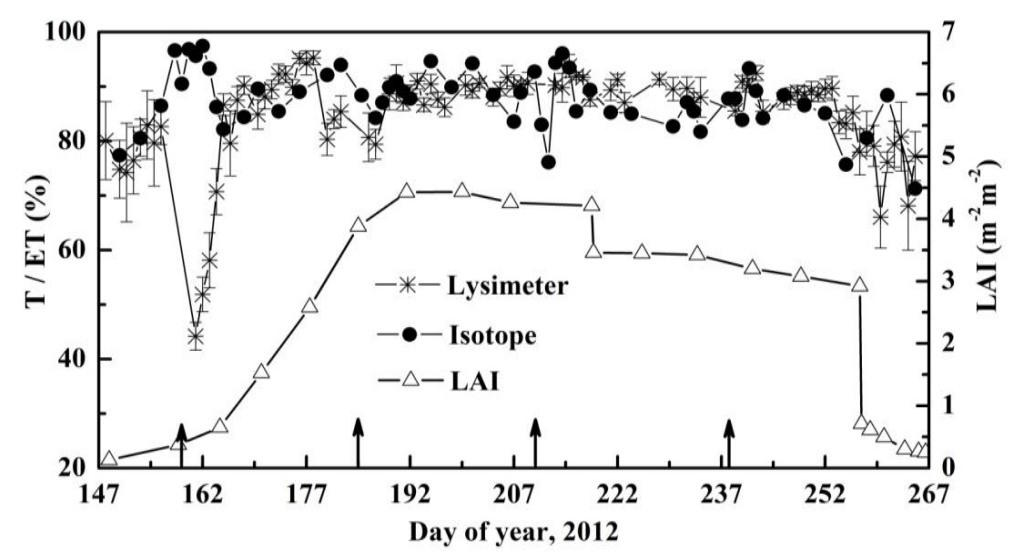




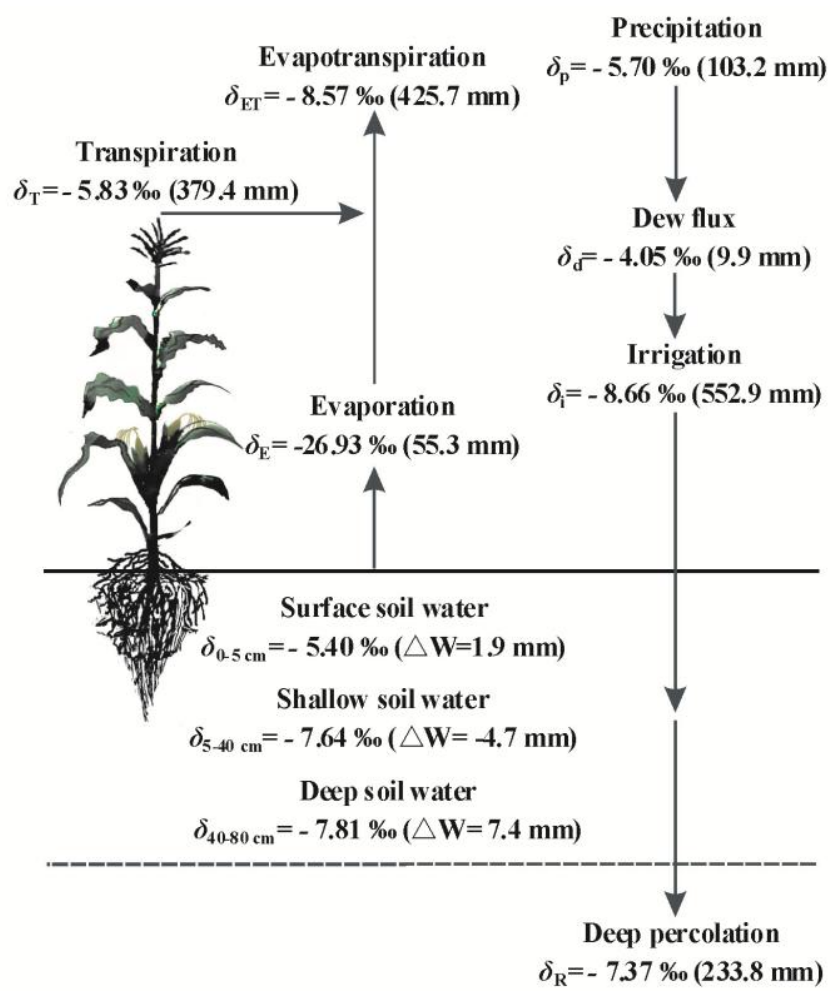

